\title{
CITAÇÃO DO INVESTIGADO NO INQUÉRITO POLICIAL: O DIREITO AO CONTRADITÓRIO E À AMPLA DEFESA EM AMBAS AS FASES DA PERSECUÇÃO PENAL
}

\author{
Juliana Gaspar Bechara* \\ Prof $^{\circ}$ Mestre Fernando Shimidt de Paula**
}

\section{RESUMO}

O tema deste artigo é amparado pelo Direito Penal e Direito Processual Penal, ramos da ciência jurídica que tratam da persecução e do caráter sancionatório nas sociedades modernas. $\mathrm{O}$ presente trabalho tem como objetivo geral analisar os princípios do contraditório e da ampla defesa na fase do inquérito policial. A escolha do tema justifica-se na relevância social de compreender os aspectos de cumprimento dos direitos dos investigados, da ampla defesa e do contraditório, os quais precisam ser respeitados para que todo o procedimento legal seja validado pela autoridade judiciária. Neste artigo reúnem-se as informações já encontradas sobre o assunto, é aplicada uma metodologia qualitativa, com foco no caráter subjetivo da bibliografia analisada, por conceitos, definições, posições e opiniões, bem como uma metodologia exploratória e descritiva, apurando-se a necessidade de aplicação dos princípios já na fase de investigação.

Palavras-chave: Citação; inquérito policial; contraditório e ampla Defesa; presunção de inocência.

\section{CITATION OF THE INVESTIGATED IN THE POLICE INVESTIGA- TION: THE RIGHT TO CONTRADICTORY AND BROAD DEFENSE IN BOTH PHASES OF CRIMINAL PROSECUTION}

\section{ABSTRACT}

The theme of this monograph finds legal basis in Criminal Law and Criminal Procedural Law, legal sciences that, delimit the pursuit and sanctioning character of modern societies. This paper has as general objective to analyze the principles of the adversary and of the wide defense in the phase of the police investigation. The choice of the theme is justified by the social relevance of understanding the aspects of compliance with the rights of the investigated, broad defense and contradiction, which need to be respected for the entire legal procedure to be validated by the judicial authority. The present work

* Bacharel em Direito pela Universidade Metodista de São Paulo, e-mail de contato: jullygaspar@ hotmail.com

** Mestre em Direito Penal pela Pontifícia Universidade Católica de São Paulo - PUC/SP. Especialista em Gestão do Comportamento pela Universidade Federal de São Paulo - UNIFESP e em Direito Público pela Escola Paulista da Magistratura - EPM. Professor da Academia de Polícia de São Paulo e Professor Universitário. E-mail para contato: feshipa@gmail.com. 
is based on a bibliographic review, since it is intended to gather the information already found on the subject, and a qualitative methodology will be applied, focusing on the subjective character of the analyzed bibliography, by concepts, definitions, positions and opinions, as well as an exploratory and descriptive methodology, the need to implement the principles already in the research phase.

Keywords: Quote; police inquiry; contradictory and broad defense; presumption of innocence.

\section{INTRODUÇ̃̃O}

Nas sociedades modernas, o papel do Estado está previamente definido nas Constituições, determinadoras dos pressupostos de criação, vigência e execução de todo ordenamento jurídico. Assim, os limites do direito de punir dependem das funções constitucionalmente previstas para o Estado que, por sua vez, deve possibilitar a convivência social e proporcionar o exercício das liberdades e controlar a violência.

Para Michel Foucault (1995), o Direito Penal trabalha como manifestação do poder, integrando a anatomia política do Estado, fazendo parte de sua tática política, portanto, ele é um instrumento político a serviço de todos, isto é, constitui uma só técnica de manejo de certos e determinados conflitos.

Apesar de o sistema criminal brasileiro passar uma imagem de morosidade da justiça, uma sensação de impunidade na qual se postulam vários e incansáveis recursos com o objetivo de apenas protelar os processos, observa-se na Constituição da República Federativa do Brasil, em seu artigo $5^{\circ}$, a asseguração dos direitos fundamentais e um rol de garantias ao cidadão, "ex vi" do inciso LVII: "ninguém será considerado culpado até o trânsito em julgado de sentença penal condenatória" (BRASIL, CF, 1988).

Trata-se do princípio da presunção da inocência, garantidor da liberdade pessoal, senão dentro dos limites legais. Princípio adotado no Brasil desde a votação na Assembleia-Geral da ONU em 1948 e previsto expressamente em nossa Constituição desde 1988, tornando-se basilar de nosso ordenamento jurídico.

Visando o princípio da presunção da inocência, Renato Marcão $(2012$, p.78) leciona " [...] não pode haver a inversão do ônus da prova. Ao estado, a quem compete à formalização da denúncia, cabe à produção das provas necessárias para tanto, asseguradas ao acusado a ampla defesa e o estabelecimento do contraditório", ou seja, é assegurado um julgamento justo e com ampla defesa, gerando confiança e segurança ao acusado que poderá somente ser declarado culpado após seu trânsito em julgado, provando assim a sua culpa.

Neste sentido, a temática escolhida para ser trabalhada ao longo deste artigo, encontra fundamentação jurídica no Direito Penal e no Direito Processual Penal, ciências jurídicas demarcadoras da persecução e o caráter sancionatório das sociedades modernas. Portanto, estudar-se-á o conjunto de leis qualificadoras de crime, seu processo e finalização, bem como a apresentação dos princípios que precisam ser aplicados dentro de todas as fases: inquérito, processo e execução, relacionando-os. (MENDES, 2015). 
Compreendido em qual delimitação científica encontra-se a temática, focaremos na fase pré-processual, na qual se avaliam os atos antecedentes ao processo e aqui trataremos da necessidade da citação do investigado no inquérito policial, envolvendo os aspectos do contraditório, da ampla defesa e da presunção de inocência, bem como se e quais requisitos devem ser respeitados pelas autoridades policiais em prol da equidade de informações e possibilidade de defesa, evitando juízos açodados e pré-julgamentos injustos. A disposição dessa parte investigatória apoia-se no Código de Processo Penal e passa a ser responsabilidade do delegado de polícia (PAULA, 2018).

Inquérito policial é definido como: “(...) um procedimento preliminar à ação penal, de natureza processual, conduzido pela Polícia Judiciária e voltado à colheita de provas da materialidade, autoria e circunstâncias da infração" (PAULA, 2018, p. 74).

Aponta-se que o inquérito policial exerce um papel fundamental para o esclarecimento das infrações penais, levando em consideração os fatos apresentados por meio das provas que subsidiam o Ministério Público e o ofendido na ação penal privada de elementos hábeis ao oferecimento da denúncia ou queixa.

Por outro lado, existe uma discussão sobre a natureza jurídica e aplicação prática dos institutos da ampla defesa e contraditório na fase investigatória, questionando-se se devem ou não ser garantidos.

Ressalta-se que a tratativa de ambos os princípios na investigação é fruto de discussão doutrinária relativa ao nível de aplicação do contraditório e ampla defesa no inquérito, levando em consideração não estar de fato na esfera judicial. Observa-se que uma das principais modificações causadas pela Lei 13.245//2016 (Reforma do Estatuto da Ordem dos Advogados do Brasil) se refere ao procedimento de investigação criminal, principalmente quanto ao direito de defesa e ao contraditório. Apesar da promoção de uma revisão estrutural desses direitos dentro dessa norma legal, houve um considerável esforço em reestruturar o entendimento basilar de reforço ao respeito dos direitos fundamentais e às garantias constitucionais.

Ressalta-se também quanto ao inquérito, em especial depois da Súmula Vinculante 14 do Supremo Tribunal Federal - STF e com a promulgação da Lei 13.245/2016, o direito à informação e à participação do investigado, enquanto assistido por defensor técnico, foi significativamente ampliado. Tanto a Súmula editada pelo STF quanto o Estatuto da Advocacia garantem as prerrogativas do Advogado de ter acesso ao conteúdo informativo desde a investigação criminal (artigo $7^{\circ}$, XIV, da Lei 8.906/94).

Dessa feita, fica assegurada em lei a possibilidade de acompanhamento técnico do investigado durante o interrogatório ou outra forma de oitiva, além dos atos subsequentes, quando assim requerido, sob pena de nulidade; podendo, inclusive, apresentar razões e quesitos (artigo $7^{\circ}$, XXI, da Lei 8.906/94).

Assim, há que se notabilizar a importância de promover o estudo dos referidos princípios, compreendendo a sua aplicabilidade à realidade investigatória 
e processual, a promoção de uma defesa técnica, a possibilidade informativa ao investigado com a investigação em curso, a possibilidade de apresentação de razões e quesitos quando necessários, embora o processo de defesa seja considerado mitigado.

Portanto, o presente trabalho tem como objetivo geral analisar os princípios do contraditório e da ampla defesa na fase do inquérito policial e, especificamente, analisar a aplicação dos princípios em uma fase procedimental levando em consideração o reflexo social e familiar de um processo investigativo; estudar a obrigatoriedade da citação nos inquéritos policiais e demais procedimentos extrajudiciais vinculados apenas aos agentes públicos; demonstrar a importância da citação do acusado no inquérito e as devidas conceituações doutrinárias e jurídicas dos institutos estudados.

A escolha do tema justifica-se pela relevância social de compreender os aspectos de cumprimento dos direitos dos investigados, a ampla defesa e o contraditório, os quais precisam ser respeitados durante todo o procedimento legal e validados pela autoridade judiciária e, desse modo, garantir os direitos fundamentais do cidadão desde a fase pré-processual, enaltecer os direitos humanos e demonstrar a imprescindibilidade da observância desses princípios basilares em nosso ordenamento jurídico.

Os princípios do contraditório e da ampla defesa no processo penal

O princípio do contraditório encontra-se positivado no art. $5^{\circ}$, inciso $\mathrm{LV}$, da Constituição Federal, que determina: "art. $5^{\circ}$, LV - aos litigantes, em processo judicial ou administrativo, e aos acusados em geral são assegurados o contraditório e ampla defesa, com os meios e recursos a ela inerentes" (BRASIL, CF, 1988). Pelo contraditório, assegura-se paridade de armas no processo, a ponto de permitir ao imputado de determinada conduta que possa produzir prova e manifestar-se em seu favor contrariamente à acusação; somente após o que o juiz, imparcial, poderá proferir sua decisão. Por este princípio, a defesa pode demonstrar, diante de todas as possibilidades, o seu discernimento sobre o litígio. (AGRA, 2018)

Renato Brasileiro de Lima (2017; p. 53/54) aponta uma classificação entre o contraditório para a prova (contraditório real) e o contraditório sobre a prova (contraditório diferido).

$\mathrm{O}$ contraditório para a prova (ou contraditório real) corresponde àquele na qual há efetiva participação das partes envolvidas sobre o elemento de prova perante o órgão julgador. Cita-se como exemplo a prova testemunhal colhida em juízo, com participação de ambas as partes na produção da prova. O contraditório sobre a prova, contraditório diferido ou postergado, trata-se de uma hipótese excepcional em relação à natureza da prova produzida, a exemplo das não repetíveis. A realização do contraditório é feita em um momento posterior. Ressalta-se que o contraditório não deixa de ser observado, porquanto seu exercício será apenas di- 
ferido para momento posterior. Como exemplo, cita-se a interceptação telefônica.

Como se vê, dá-se ao investigado a oportunidade de provar o contrário, por meio de defensor, na tentativa de buscar uma igualdade substancial.

Outrossim, conforme indicado, o direito da defesa, tal qual o contraditório, está garantido na Constituição pelo inc. LV do art. $5^{\circ}$. "Na perspectiva de direito público, a defesa é mais que um direito, constitui uma garantia do acusado de um lado e do justo processo do outro".

A despeito do direito de defesa estar ligado diretamente ao princípio do contraditório, ambos não se confundem. A ampla defesa apresenta-se como garantia ao exercício do princípio do contraditório e por intermédio dele é manifestada, ao mesmo tempo em que a ampla defesa somente é possível pelos elementos do contraditório: paridade de armas, direito à informação e à reação.

Contudo, por se tratar de princípios distintos, indaga-se a possibilidade da inobservância de um sem prejuízo do outro. Nesse sentido, Gustavo Badaró (2009, p. 37) aponta pela possibilidade de se ferir o direito ao contraditório sem prejuízo da ampla defesa.

É possível violar-se o contraditório, sem que se lesione o direito de defesa. Não se pode esquecer que o princípio do contraditório não diz respeito apenas à defesa ou aos direitos do réu. O princípio deve aplicar-se em relação a ambas as partes, além de também ser observado pelo próprio juiz. Deixar de comunicar um determinado ato processual ao acusador, ou impedir-lhe a reação à determinada prova ou alegação da defesa, embora não represente violação do direito de defesa, certamente violará o princípio do contraditório. O contraditório manifesta-se em relação a ambas as partes, ja $\square$ a defesa diz respeito apenas ao réu

Embora o princípio do contraditório esteja interligado ao direito de defesa, também garante à acusação informação e reação.

Com efeito, por intermédio do conhecimento de uma informação, o acusado tem uma reação e deve vir a expressar-se. Fazendo parte do devido processo legal, cabe a cada uma das partes o exercício de sua defesa, decorrente disso, quando apresentado algum termo, cabe a outra parte contrapor-se aos argumentos por meio do contraditório. Lima (2020) aponta que ao haver prática de ato ou argumento processual não comunicado à outra parte, se não for considerado desrespeito ao princípio da ampla defesa, o será pelo contraditório, pois devem ser aplicados a ambas as partes.

“Sendo assim, preliminarmente, é possível considerar que este princípio possibilita ao réu o direito de utilizar-se de amplas e extensas formas para se defender da acusação que lhe é imputada" (PAULA, 2018, p. 89). Alude-se ao princípio da ampla defesa como ligado ao direito à informação, um dos elementos que compõem o princípio do contraditório, assim o direito de defesa conectado diretamente a este outro princípio, porém eles não se confundem.

A ampla defesa é o princípio capaz de conceber ao réu a possibilidade de exercer todos os direitos no processo, permitindo o alcance do esclarecimento da 
verdade, de se omitir ou de ficar em silêncio, se assim decidir. (MORAES, 2017). "A ampla defesa pode ser dividida em pessoal, ou autodefesa, feita pelo próprio acusado, e técnica realizada por defensor constituído ou dativo, bem como por intermédio da defensoria pública". (PAULA, 2018, p. 88).

Ademais, consideram-se meios inerentes à ampla defesa

Ter conhecimento claro da imputação;

Poder apresentar alegações contra a acusação;

Poder acompanhar a prova produzida e fazer contraprova;

Ter defesa técnica por advogado, cuja função, aliás, agora, é essencial à Administração da Justiça (CF, art.133); e

Poder recorrer da decisão desfavorável

Em relação à sistematização da defesa, ao acusado são direcionados benefícios que só a ele cabe exercer. Nesse ponto, existem previsões sobre os recursos concernentes apenas à defesa, a clara manifestação da proibição da reformatio in pejus, a regra do in dubio pro reo, o direito de revisão criminal exclusivamente pro reo etc. (LIMA, 2020, p. 59) Além destes, também, o chamado de princípio do favor rei, tido como objeto primordial do Estado Constitucionalmente Democrático, segundo o qual, diante de determinada situação, o operador do Direito deve analisar as divergências das normas e decidir por aquela que preveja o jus libertatis do acusado.

Nesse sentido, deverá ser aplicada com base na previsão mais favorável ao réu, quando não houver nos autos, por exemplo, provas suficientes acarretadoras de condenação. (RANGEL, 2019). Assim, para delimitar o conteúdo jurídico do princípio da ampla defesa, a doutrina costuma classificá-la de duas maneiras distintas: a primeira, entre a defesa técnica e a segunda a autodefesa, as quais são subdivididas em defesa positiva e defesa negativa.

A defesa técnica é a exercida, necessariamente, por profissional do Direito, dotado de capacidade postulatória. Seu fundamento reside na necessidade de equilibrar as partes, notadamente em razão da hipossuficiência presumida do acusado em face da acusação. Destaca-se: a defesa técnica não é uma faculdade do acusado; é imperiosa a presença de um defensor para a regularidade da demanda legada a juízo e para a concretização do devido processo legal. Por essa razão, a defesa técnica é necessária, indeclinável, plena e efetiva. Por sua vez a autodefesa diferencia-se da defesa técnica, porque exercida pelo próprio acusado. Embora disponível, porque aos acusados se atribui o direito ao silêncio, a autodefesa revela-se de suma relevância para o deslinde das causas.

Trataremos a seguir do inquérito policial, fase pré processual na qual pretendemos também ver aplicados os princípios até aqui analisados.

\section{Do inquérito policial}

O inquérito é um procedimento administrativo averiguador da instrução provisória de atribuição da polícia judiciária. A partir do momento em que uma infração penal é cometida torna-se obrigação do Estado perseguir e punir seu autor. Por 
isso, neste momento apresentaremos o conceito e a evolução histórica do inquérito policial, suas principais características e aspectos do sistema misto de persecução penal brasileiro.

\title{
Conceito e evolução histórica
}

Referente à relevância do inquérito policial, Fernando Shimidt de Paula, delegado e professor, afirma (2018, p. 43):

\begin{abstract}
O inquérito policial é, indubitavelmente, o procedimento investigatório mais importante a subsidiar o Ministério Público dos elementos de prova para a formação da sua opinio delicti e, com isso, possibilitar o oferecimento, ou não, de denúncia em face do indivíduo apontado como autor do crime, ou contravenção penal.
\end{abstract}

Para o Estado iniciar a persecução criminal em juízo é essencial a presença de elementos de informação suficientes sobre a autoria e a materialidade da infração penal que, como se sabe, no mais das vezes são obtidos pela investigação policial.

Nos crimes comuns, a investigação é realizada pelos órgãos estatais com atribuição de Polícia Judiciária, que se utiliza do inquérito policial como instrumento a captar elementos de prova com o objetivo de analisar circunstâncias e estabelecer a autoria. Os órgãos com essa atribuição são as Polícias Civis dos Estados e do Distrito Federal, quando competente for a Justiça Estadual, e a Polícia Federal, quando a competência recair na Justiça Federal. A condução do inquérito policial é feita pelo Delegado de Polícia ou pelo Delegado de Polícia Federal. (PACELLI, 2020)

No Brasil, por séculos, as funções investigativa e jurisdicional se misturavam e se tinha na pessoa do juiz a autoridade encarregada da persecução penal, tanto na investigação como no processo. Somente no ano de 1870, com o advento da Lei $\mathrm{n}^{\mathrm{o}} 2.033$, foram separadas as funções de polícia e judiciais (jurisdicionais), dando origem ao inquérito policial. O inquérito policial teve sua formulação concretizada por meio do Decreto $\mathrm{n}^{\circ} 4.824$, de 1871, sucessor da Lei de 3 de dezembro de 1841 e do Regulamento 120, de 31 de dezembro de 1842 cujo objetivo era garantir direitos aos investigados. (FERNANDES, 2005).

Atualmente, diante da Constituição Federal, o objetivo primordial do inquérito policial é assegurar o direito à inviolabilidade da intimidade, da vida privada, da honra e da imagem dos investigados, seguindo os preceitos do art. $5^{\circ}, \mathrm{X}$, da Lei Maior. As investigações devem ser realizadas levando-se em consideração os aspectos relacionados à presunção de inocência, que abrange todos os cidadãos, impedindo-se juízos de valor antecipados.

Dentre as características componentes do inquérito policial temos a oficialidade e segundo Fernando Capez (2005, p. 50) “somente os órgãos de direito público é que estão autorizados a promover as atividades investigativas, inobstante haver em nosso ordenamento jurídico a possibilidade jurídica de ajuizamento de queixa-crime". Somente a autoridade constituída pelo poder público exerce poder in- 
vestigatório, no caso o Delegado de Polícia, que ocupa cargo público após rigoroso processo de seleção por meio de provas e títulos.

Outra característica do inquérito policial é sua dispensabilidade, ou seja, não é requisito objetivo de procedibilidade para a ação penal, a qual pode ser intentada com base em outras provas. Contudo, por força do artigo 17 do Código de Processo Penal, a autoridade policial não pode mandar arquivar os autos do inquérito policial.

O inquérito policial é um documento formal, deve ser escrito e assinado pela autoridade policial; além disso, é sistemático, todos os atos devem ser inseridos no inquérito policial de forma cronológica para melhor compreensão do que for angariado. Tem direção una, ou seja, visa apurar fato determinado e sigiloso, para garantir a intimidade dos envolvidos e para não atrapalhar o curso das investigações. Visto o inquérito não ter forma pré-estabelecida para ser formalizado, o Delegado de Polícia deve agir de forma discricionária, mas limitado pela lei. (RANGEL, 2019)

Quanto ao sigilo, uma ressalva: não alcança o representante do Ministério Público e a autoridade judiciária, bem como os advogados na defesa de seus clientes, porquanto podem consultar os autos do inquérito.

Ressalte-se também o princípio da dignidade da pessoa humana, um dos fundamentos da República (BRASIL, CF, 1988, art. 1o, inciso III), garantido pelo inquérito policial porque evita a submissão de cidadãos a processos judiciais sem provas.

Sistema inquisitorial e acusatório

O sistema inquisitorial marcou época com o Direito Canônico no século XIII e era caracterizado pela concentração em uma só pessoa do exercício das funções de investigar, acusar, defender e julgar, pessoa intitulada como juiz acusador/inquisidor. Não havia imparcialidade tampouco o contraditório, não sendo possível o exercício de defesa e, na maioria das vezes, o acusado era preso preventivamente, sem comunicação. (LIMA, 2020)

No sistema acusatório, por sua vez, cada órgão exerce sua função: investigar, acusar e julgar, e o processo tem início com a apresentação formal da acusação. No sistema acusatório, segundo Rangel (2019), há distinção e separações de incumbências, o juiz transfigura um órgão dotado de imparcialidade e aplicador da lei e não pode agir de ofício, deve ser provocado para que se manifeste.

Ao autor cabe formular a acusação. O Estado dispõe de órgão específico para esse mister, o Ministério Público, o qual colaciona provas sobre a prática de um fato criminoso e pede condenação do infrator, enquanto este, denominado réu, exerce seu direito de defesa por todos os meios admitidos. A publicidade faz parte dos procedimentos, podendo em alguns casos ser mantidos em sigilo. Inafastáveis o contraditório e a ampla defesa, atua o juiz com livre convencimento das provas carreadas nos autos. 


\section{Sistema misto e sistema brasileiro}

O sistema misto foi instituído a partir da fusão dos sistemas inquisitivo e acusatório. Surgiu em 1808 na França governada por Napoleão Bonaparte. Abarca ambos os sistemas em duas fases de seu procedimento, por isso é chamado misto.

Na primeira fase, inquisitorial, não há publicidade e ampla defesa, possui formulação escrita e caráter sigiloso. Não há acusação e nem contraditório. Trata-se da investigação inicial, da instrução com atos preparatórios, na qual o juiz verifica pressupostos de materialidade e autoria do crime.

Já a segunda fase, a acusatória, tem início com o oferecimento de denúncia pelo órgão encarregado da acusação e o réu tem o direito de apresentar sua defesa para, ao final, o juiz proferir seu julgamento. Aqui reina a prevalência da publicidade, da oralidade, da isonomia processual e consagra-se o direito de a defesa opor-se aos argumentos, provas e fatos aduzidos pela acusação. (LIMA, 2020)

Atualmente, com as alterações efetivadas pela Lei $n^{\circ}$ 13.964/2019 (Pacote Anticrime), criou-se a figura do juiz de garantias, que irá atuar somente na fase de investigação, sendo a ele vedado promover iniciativa relacionada à investigação. Ademais, caso haja o desenvolvimento de qualquer conduta pertinente ao Inquérito Policial e à acusação, o juiz não poderá funcionar no respectivo processo. Conforme art. $3^{\circ}$ da Lei:

Art. $3^{\circ}$-A. O processo penal terá estrutura acusatória, vedadas a iniciativa do juiz na fase de investigação e a substituição da atuação probatória do órgão de acusação.

Art. $3^{\circ}$-B. O juiz das garantias é responsável pelo controle da legalidade da investigação criminal e pela salvaguarda dos direitos individuais cuja franquia tenha sido reservada à autorização prévia do Poder Judiciário, competindo-lhe especialmente: [...]

$\mathrm{V}$ - ser informado sobre a instauração de qualquer investigação criminal; $[\ldots]$

Art. $3^{\circ}$-D. O juiz que, na fase de investigação, praticar qualquer ato incluído nas competências dos arts. $4^{\circ}$ e $5^{\circ}$ deste Código ficará impedido de funcionar no processo. [...] (BRASIL, Lei no 13.964, 2019)

Para Rangel (2019), apesar de não ser considerado puro, o Brasil adota o sistema acusatório, uma vez que quando da instauração e trâmite do inquérito policial, baseado no sigilo e na inquisitoriedade, o indiciado não é visto como sujeito de direitos, mas "como objeto de investigação, integra os autos do processo, e o juiz, muitas vezes, pergunta, em audiência, se os fatos que constam do inquérito policial são verdadeiros" (RANGEL, 2019, p. 128). Desta forma, existiriam duas fases distintas, uma investigativa e outra acusatória.

\section{A citação no processo penal}


A citação é o instrumento legal por meio do qual o Estado dá ciência ao réu ou ao interessado sobre a existência de um processo em andamento, permitindo a realização da sua defesa. Aqui apresentaremos os principais aspectos da citação, pontuando sobre a citação na persecução penal e a sua natureza jurídica, além de versar sobre a citação no inquérito policial e a possibilidade de extensão da citação extrajudicial para todos os investigados, tema central deste estudo.

\section{Principais aspectos da citação}

O processo só é completo quando ambas as partes têm ciência da sua existência. A citação é um ato obrigatório em todos os processos, de modo que sua não realização ou realização viciada invalida o andamento do processo, ainda que haja trânsito em julgado.

De extrema importância ressaltar a indispensabilidade da citação, porquanto existe justamente para garantir a ampla defesa e o contraditório, permitindo ao investigado saber o que existe contra si e se organizar para se contrapor e produzir prova em seu favor. Assim, em resumo, apresentam-se os principais aspectos da citação, conforme o Código de Processo Civil (BRASIL, CPC, 2015):

a) conceito: a citação é ato pelo qual existe a convocação do réu, executado ou interessado de integrar a relação processual, para validade de todo o processo é indispensável à citação do réu;

b) características: trata-se de um pressuposto processual de existência do processo; é uma condição de eficácia em relação ao réu. Conforme disposto no artigo 246 do CPC, a citação pode concretizar-se pelo correio, por oficial de justiça, pelo escrivão ou chefe de secretaria, se o citando comparecer em cartório, por edital ou por meio eletrônico, conforme regulado em lei;

c) consequências: executada pelo juízo competente, pode induzir a litispendência, torna litigiosa a coisa e constitui em mora o devedor, ressalvado o disposto nos artigos 397 e 398 do Código Civil e a citação válida interrompe o prazo prescricional.;

d) aplicação: a citação é aplicada nos processos em que haja o interesse jurídico de discutir determinada temática, seja ela criminal ou não. Ressalta-se que, em regra, a citação deve ser sempre pessoal, podendo recair na pessoa do réu, do executado, do interessado ou do seu representante legal ou procurador.

O CPC (BRASIL. 2015) é o principal responsável pela delimitação da citação, apresentando diversas especificações, com a citação indireta realizada na pessoa do procurador legalmente habilitado, do advogado ou de terceiros detentores de poderes para vincular o réu ou, ainda, por força de contrato. $\mathrm{O}$ artigo 242 , §1 ${ }^{\circ}$ do CPC estipula: "Na ausência do citando, a citação será feita na pessoa de seu mandatário, administrador, preposto ou gerente, quando a ação se originar de atos por eles praticados", mas, existem os casos em que mesmo com a ausência do réu mediante a presença de procurador com poderes especiais existirá a citação. 


\section{Citação na persecução penal e sua natureza jurídica}

Para que haja a correta execução da persecução penal devem ser observados os procedimentos e atos previstos no ordenamento jurídico, seja no Código de Processo Penal (BRASIL, CPP, 1941) ou, ainda, na legislação especial. Contudo, apenas o cumprimento dos procedimentos de forma correta não assegura o respeito ao processo legal, é necessária a comunicação de todos os atos processuais aos envolvidos, respeitando os limites legais; para isso temos o instituto da citação, notificação e intimação. O Pacote Anticrime acarretou na necessidade de citação do servidor integrante das forças de segurança pública quando envolvido em fatos típicos, mas aparentemente acobertados por excludente de antijuridicidade. Sobre isso, apresentamos o posicionamento do doutrinador Renato Brasileiro de Lima (2020, p.192):

Evidente a impropriedade técnica do dispositivo ao fazer uso do termo "citação", sabidamente conhecido como o ato de comunicação processual que dá ciência ao acusado acerca da instauração de um processo penal - e não de uma investigação criminal - contra a sua pessoa, chamando-o para se defender. Portanto, o ideal é substituirmos o termo citado por notificado, notificação esta que poderá ser feita por qualquer meio de comunicação (v.g., pessoal, e-mail, carta, WhatsApp etc. (grifo do autor)

A citação não pode ser confundida com a intimação, isso porque a citação é o ato processual responsável por chamar o réu ao processo, dando-lhe ciência sobre a acusação e abrindo-lhe a oportunidade de ofertar defesa técnica.

Por outro lado, quando do cometimento de uma infração penal, cabe ao Estado-Administração, por meio de órgãos próprios, levar ao conhecimento do juiz a notícia do fato para que ele diga se o pretenso autor deve ou não ser punido. Esta atitude do Estado denomina-se persecutio criminis, é neste momento que a perseguição ao crime tem seu início. O Estado é o titular do direito de punir (poder soberano) e, com o intuito de proteger a comunidade, instituiu dois organismos dedicados a essa atividade: a Polícia Judiciária e o Ministério Público.

Assim, Didier (2015) faz referência ao novo Código de Processo Civil, delineia a citação como condição de eficácia do processo em relação ao réu e requisito de validade dos atos processuais seguintes, podendo levar à anulação de todo o processo quando não realizada em tempo oportuno. Porque, se não houve a devida citação, o processo não existe juridicamente para o réu até que ele seja validamente citado. Logo, não pode sofrer as consequências de uma sentença proferida em seu desfavor, pois não lhe foi dada a oportunidade para que pudesse exercer o contraditório e a ampla defesa.

A pergunta que se faz é sobre a possibilidade desse ato de ciência e chama- 
mento para se defender ocorrer antes da acusação, ou seja, na fase de investigação, como pretendeu o legislador ao criar o $\S 1^{\circ}$ do artigo 14-A do Código de Processo Penal: "Para os casos previstos no caput deste artigo, o investigado deverá ser citado da instauração do procedimento investigatório..." (BRASIL, 2020 - grifos nossos).

Por isso, pensamos que o investigado deve ter garantidos seus direitos fundamentais já na fase preliminar, para viabilizar sua defesa. A seguir, abordaremos especificamente a citação no inquérito policial.

A citação no inquérito policial

A simples deflagração de uma investigação já é capaz de atingir o chamado status dignitatis do imputado, afinal atualmente a mídia noticia a instauração de um inquérito policial como sinônimo de verdade tal qual uma condenação transitada em julgado. Por isso, não se admite a instauração de procedimentos de investigação manifestamente levianos, temerários, carentes de um lastro mínimo de indícios da prática do crime.

Por conseguinte, nenhum indivíduo deve ser submetido indevidamente aos constrangimentos ilegais advindos de um processo criminal leviano e temerário (strepitus judicii), assim como não pode ser objeto de investigação indevida (strepitus investigationem). Assim, não se admite a deflagração de um processo de investigação sem um mínimo de indícios sobre a materialidade e/ou autoria de um delito (LIMA, 2020).

Sobre o controle de acesso aos atos investigatórios, importante destacar que a Lei Federal 8.906/94 (Estatuto da Advocacia e da OAB) garante ao advogado "examinar, em qualquer repartição policial, mesmo sem procuração, autos de flagrante e de inquérito, findos ou em andamento, ainda que conclusos à autoridade, podendo copiar peças e tomar apontamentos" (artigo $7^{\circ}$, XIV) e a Súmula Vinculante $\mathrm{n}^{\mathrm{o}} 14$ do Supremo Tribunal Federal estabelece: “É direito do defensor, no interesse do representado, ter acesso amplo aos elementos de prova que, já documentados em procedimento investigatório realizado por órgão com competência de polícia judiciária, digam respeito ao exercício do direito de defesa."

Nesse diapasão, o artigo $9^{\circ}$ do Código de Processo Penal (CPP) preceitua: "As peças do inquérito policial serão processadas e reduzidas a escrito ou datilografadas e, neste caso, rubricadas pela autoridade" (BRASIL, 1941), passíveis de fiscalização interna e externa. $\mathrm{O}$ inquérito policial possui caráter pré-determinado por ser procedimento informativo que pretende, por meio de suas diligências, a colheita de todos os elementos possíveis da materialidade e da autoria delitivas para que o Ministério Público possa dele se valer e justificar eventual propositura de ação penal.

Por seu turno, o chamado contraditório mitigado ou diferido, assim denominado por estar presente perante o inquérito policial no tangente ao colhimento de 
provas urgentes impossibilitadas de serem repetidas quando na fase processual, são realizadas durante a investigação criminal, mas admitidas ou não somente na fase judicial. A tese aqui elencada é a da inexistência de acusação nessa fase, impedindo a manifestação do contraditório.

Entretanto, o não uso do contraditório nesta fase pode acarretar vários prejuízos aos investigados, considerando as consequências negativas causadas pelas provas não passíveis de impugnação. Uma vez colhidas e impossibilitadas contra-argumentações, certo é que essas provas podem tornar-se fonte para uma condenação. (THEMUDO, 2017)

Bem por isso, alguns doutrinadores entendem a possibilidade de se efetivar a defesa já no curso das investigações, tratando-se de verdadeira "defesa pessoal" ou "autodefesa", meio pelo qual o investigado pode falar em seu interesse, expressar a verdade em seu favor (autodefesa positiva) ou permanecer em silêncio (autodefesa negativa) - direito constitucional previsto no artigo $5^{\circ}$, inciso LXIII da Carta Magna (1988).

Vale destacar o direito ao contraditório e à ampla defesa perante o inquérito policial: são de suma importância para o investigado, porque a ele é atribuído direito à informação, por conseguinte, deve ter conhecimento sobre os fatos narrados e atos realizados integrantes da investigação a ele dirigida. Nesse ponto, poderá formalizar sua autodefesa nos autos do inquérito policial e, mais, propor a produção de provas em seu favor. Em vista disso, a Lei 13.245/2016 acrescenta prerrogativa ao advogado de acompanhar o interrogatório do seu cliente.

Outrossim, na investigação policial deve ser permitido ao investigado aferir respostas decorrentes das provas produzidas em seu desfavor e solicitar as que possam ser realizadas em seu benefício, a critério do Delegado de Polícia, a quem compete decidir sobre o seu deferimento ou não, visto o caráter discricionário da investigação.

Desse modo, existe no inquérito policial verdadeiro contraditório, mitigado é verdade, mas conforme estabelecido na Súmula 14 do STF, o investigado pode valer-se de advogado ou ele próprio pode exercer sua autodefesa. Como se sabe, ao advogado é permitida a visualização das provas e atos após serem documentados e, quanto ao interrogatório, cumpre ressaltar que não é obrigatória a presença de advogado, mas se comparecer, sua presença não pode ser indeferida. (PAULA, 2018)

Paula (2018) cita Eilbaum (2005) ao informar que o inquérito policial é o primeiro contato jurídico tido com os elementos do crime. É feita a formalização dos fatos por meio de descrições, de provas obtidas e do relatório do Delegado ao final, mostrando sua importância para a elucidação do ocorrido e para o andamento do processo penal. O inquérito policial configura-se como procedimento basilar da concepção da culpa, há uma coleta de elementos de provas apoiadores da possível acusação a ser realizada pelo Ministério Público. A partir dessas provas é que a decisão judicial recebe ou não a denúncia e determina eventuais providências que no inquérito policial não se pôde concluir. 


\section{Extensão da citação extrajudicial para todos os investigados}

A reforma integrada pela Lei 13.964/2019 voltou toda sua atenção para o direito de defesa de agentes públicos enumerados no art. 144 da Constituição Federal (polícia federal, polícia rodoviária federal, polícia ferroviária federal, polícias civis, militares e corpos de bombeiros militares, polícias penais federal, estaduais e distritais) em medida exagerada, a qual já previa a instituição de defesa formal durante a investigação.

A Lei supracitada permitiu aos agentes policiais a possibilidade de gozar de assistência jurídica na fase do inquérito, fase tida como inquisitiva ausente o contraditório. Desse modo, o art. 14-A do CPP instituiu que esses agentes policiais possuem o direito de constituírem defesa formal ainda na fase investigatória (NUCCI, 2020):

Art. 14-A. Nos casos em que servidores vinculados às instituições dispostas no art. 144 da Constituição Federal figurarem como investigados em inquéritos policiais, inquéritos policiais militares e demais procedimentos extrajudiciais, cujo objeto for a investigação de fatos relacionados ao uso da força letal praticados no exercício profissional, de forma consumada ou tentada, incluindo as situações dispostas no art. 23 do Decreto-Lei n ${ }^{\circ}$ 2.848, de 7 de dezembro de 1940 (Código Penal), o indiciado poderá constituir defensor. (Incluído pela Lei $n^{\circ} 13.964$, de 2019). $\S 1^{\circ}$ Para os casos previstos no caput deste artigo, o investigado deverá ser citado da instauração do procedimento investigatório, podendo constituir defensor no prazo de até 48 (quarenta e oito) horas a contar do recebimento da citação.

$\S 2^{\circ}$ Esgotado o prazo disposto no $\S 1^{\circ}$ deste artigo com ausência de nomeação de defensor pelo investigado, a autoridade responsável pela investigação deverá intimar a instituição a que estava vinculado o investigado à época da ocorrência dos fatos, para que essa, no prazo de 48 (quarenta e oito) horas, indique defensor para a representação do investigado. (Incluído pela Lei ${ }^{\circ}$ 13.964, de 2019);

(..)

$\S 6^{\circ}$ As disposições constantes deste artigo se aplicam aos servidores militares vinculados às instituições dispostas no art. 142 da Constituição Federal, desde que os fatos investigados digam respeito a missões para a Garantia da Lei e da Ordem (Incluído pela Lei n 13.964, de 2019).

Esse dispositivo foi constituído de forma detalhada para a proteção dos agentes policiais que se envolvam em investigação de fatos relacionados ao uso da força letal praticados no exercício profissional, de forma consumada ou tentada. O agente policial recebe a prerrogativa de se defender já na fase de investigação, para evitar eventual processo judicial injusto. Entretanto, salvo melhor juízo, todos que cometem infrações penais têm direito a um tratamento igual, especialmente se cometerem crimes recorrentes, como é o homicídio, consistente em matar uma pessoa, não sendo válida a diferenciação se o ato foi praticado no exercício da 
atividade policial, porquanto tão grave quanto matar um indivíduo em qualquer outro cenário.

Assim, ousamos defender a incoerência dessa discriminação positiva em favor somente dos agentes aplicadores da lei na fase do inquérito policial enquanto os demais da sociedade só poderão fazê-lo em juízo, já que o artigo $5^{\circ}$ da nossa Constituição Federal (1988) estabelece que todos somos iguais perante a lei.

Segundo Lima (2020, p.192), as adições trazidas por esse dispositivo merecem algumas considerações, o caput não trouxe inovação jurídica, deve ser interpretado de acordo com a Carta Magna e o termo "citado", incluído no $\S 1^{\circ}$ teria sido descrito erroneamente, devendo ser interpretado como notificado, porque sabemos que a citação é "o ato de comunicação processual que dá ciência ao acusado acerca da instauração de um processo penal - e não de uma investigação criminal - contra a sua pessoa, chamando-o para se defender". Entretanto, se sancionado pelo Presidente da República e convertido em lei, temos que vê-lo como um avanço na defesa dos direitos individuais e como paradigma para os demais membros da sociedade.

\section{Do direito ao contraditório e ampla defesa no inquérito}

Como vimos, o inquérito policial pode ser definido como um procedimento de preparação da ação penal de ordem administrativa, sendo guiado pela polícia judiciária com o objetivo de buscar provas para a apuração de uma infração penal (crime ou contravenção), assim como para a identificação de sua autoria. Embora classicamente se entenda pela inexistência do contraditório e da ampla defesa em sede de inquérito policial, a Lei $\mathrm{n}^{\circ}$ 13.964/2019 introduziu o precitado artigo 14-B no Código de Processo Penal, determinando a citação de agentes públicos em inquéritos e procedimentos extrajudiciais quando envolvidos em ocorrências de morte em oposição à intervenção policial, numa clara intenção de ver ambos os institutos já na fase pré-processual.

\section{Citação do agente público em inquéritos e procedimentos extrajudiciais}

A citação é o ato processual pelo qual se convoca o réu, o executado ou o interessado a compor o processo, conforme art. 238 do CPC. Esse ato tem dois objetivos, o primeiro chamar o indivíduo a juízo e o segundo dar-lhe ciência a respeito do conteúdo da demanda (DIDIER JÚNIOR, 2017).

A citação é um pressuposto de garantia de eficácia do processo, tanto na jurisdição contenciosa quanto na voluntária, é a primeira oportunidade de o citando manifestar-se e defender-se (GONÇALVES, 2018).

Sobre agente público, pode ser definido como toda pessoa física prestadora de serviços ao Estado e às pessoas jurídicas da administração indireta.

Antes da Constituição vigente, havia exclusão do conceito de agente público daquelas pessoas que prestavam serviços às pessoas jurídicas de direito privado 
instituídas pelo Poder Público. Porém, hoje estão elas todas incluídas por disciplina do art. 37 da CF/88. Assim, são quatro as categorias de agentes públicos: i. agentes políticos; ii. servidores públicos; iii. militares e iv. particulares em colaboração com o Poder Público.

No âmbito do inquérito policial sempre se pensou na inexistência de citação, mas sim de notificação, em razão da ausência de relação processual de forma triangular, ou seja, não há um terceiro imparcial para o julgamento, sendo a constituição de um defensor facultativa ao acusado (HOFFMANN; FONTES; SILVA, 2020). No âmbito do processo administrativo, principalmente do processo administrativo disciplinar contra servidor público, existem algumas modalidades de tomada de conhecimento do interessado no processo, como a intimação por ciência no processo, caso em que o acusado declara nos próprios autos sua ciência dos atos e termos nele constantes até aquele momento.

Implicações da Lei 13.964/2019

A Lei 13.964/2019 foi publicada na data de 24 de dezembro de 2019, entrando em vigor dia 23 de janeiro de 2020, sendo proveniente de um projeto do Governo denominado Pacote Anticrime. Incluiu os artigos $3^{\circ}$-A a $3^{\circ}$ - F no CPP, instituindo o juiz das garantias, revelando a intenção do legislador em garantir imparcialidade e acesso e produção de provas aos investigados em sede de inquérito policial, mas o Supremo Tribunal Federal suspendeu sua vigência sem prazo determinado. Porém, outras importantes modificações foram realizadas tanto no Código Penal quanto no Código de Processo Penal e nas Leis Especiais, são elas:

- Extensão da legítima defesa - artigo 25 do CP;

- Execução da pena de multa - artigo 51 do CP;

- Limite da pena privativa de liberdade para 40 anos - artigo 75 , caput, $\S 1^{\circ}$ do CP;

- Livramento Condicional - artigo 83, III, do CP; artigo 112, VI, alínea "a", e artigo 112, VIII ambos da LEP;

- Perda do Produto ou Proveito do Crime - artigo 91-A e 92-A, ambos do $\mathrm{CP}$;

- Causas suspensivas da prescrição - artigo 116 do CP;

- Novas qualificadoras do crime de roubo - artigo $157, \S 2^{\circ}$, VII e $\S 2^{\circ}$-B do $\mathrm{CP}$;

- Ação Penal Pública Condicionada para o crime de estelionato - artigo 171, $\S 5^{\circ}$ do $\mathrm{CP}$;

- Nova pena do crime de concussão - artigo 316 do CP;

- Proteção à cadeia de custódia da prova - artigos 158-A a 158-F do CPP;

- Garantias defensivas especiais para agentes de segurança pública artigo 14-A do CPP; 
- Modificação do regramento legal atinente ao arquivamento de inquéritos - artigo 28 do CPP;

- Criou-se legislativamente o acordo de não persecução penal para crimes de média gravidade - artigo 28-A do CPP;

- Foi alterado o tratamento da alienação de coisas apreendidas - artigo 122, bem como da destinação de obras de arte que tenham sido objeto de perdimento - artigo 124-A e venda - artigo 133 e utilização por agências públicas - artigo 133-A de outros bens, todos do CPP;

- Garantias contra o uso indevido de provas ilícitas - artigo $157, \S 5^{\circ}$ do CPP;

- Medidas cautelares que sejam decretadas pelo Juiz sem prévio pedido do Ministério Público ou representação da autoridade policial - artigo 282, § $2^{\circ}$ do CPP;

- Importância das Audiências de custódia - artigo 310 do CPP;

- Necessidade de a decretação da prisão preventiva ser concretamente justificada - artigos 311, 312, 313, 315 e 316, todos do CPP;

- Devida efetividade no processo penal - artigo 315, $\S 2^{\circ}$ do CPP e garantia constitucional da motivação das decisões judiciais - artigo 93, IX, da CF;

- Execução provisória de penas impostas pelo Tribunal do Júri - artigo 492 do CPP; e

- Alteração do sistema de nulidades - artigo 564, V do CPP, e o recursal artigos 581, XXV e 638 do CPP.

- Crimes Hediondos - Lei n ${ }^{\circ}$ 8.072/90;

- Lei das Organizações Criminosas - Lei no 12.850/13;

- Estatuto do Desarmamento - Lei n ${ }^{\circ}$ 10.826/03;

- Processos de competência originária do STF e do STJ - Lei no 8.038/90;

- Lei de Drogas - Lei ${ }^{\circ} 11.343 / 06$;

- Lei de Lavagem de Capitais - Lei no 9.613/98;

- Lei da Improbidade Administrativa - Lei no 8.429/92;

- Lei de Interceptações Telefônicas - Lei no 9.296/96;

- Lei de Execução Penal - Lei no 7.210/84;

- Estabelecimentos Penais Federais de Segurança Máxima - Lei nº 11.671/08;

- Identificação Criminal - Lei 12.037/09

- Julgamento Colegiado em Primeiro Grau - Lei n ${ }^{\circ}$ 12.694/12;

- Lei do “Disque-denúncia" - Lei no 13.608/18.

Assim, a Lei 13.964/2019, conhecida como Pacote Anticrime, apresentou uma série de modificações em diversas leis penais e processuais penais, as quais, salvo melhor juízo, transformaram o sistema acusatório misto em sistema acusatório puro.

Como já mencionado, uma das grandes modificações ocorreu com o art. 3-A do Código de Processo Penal, que estabeleceu o chamado juiz das garantias, o qual realiza uma divisão entre o juiz atuante no início do inquérito policial, daquele que analisará e julgará o caso posteriormente após o oferecimento da denúncia ou 
queixa.

Além disso, ressalte-se ser agora obrigatória a defesa durante o inquérito policial quando a investigação envolver policiais e militares. Policiais conforme rol estabelecido no art. 144 da CF/ 88 e os militares que atuem em nome da garantia da lei e da ordem, segundo o que dispõe o art. 142 da Lei Maior. Assim, caso figurem como investigados em inquéritos policiais, inquéritos policiais militares ou outro tipo de procedimento investigatório, em virtude do uso da força letal durante o exercício da atividade profissional, com evento de morte ou na modalidade tentada, mesmo clara alguma causa excludente de antijuridicidade, a teor do artigo 25 do Código Penal, os agentes têm o direito de ser citados e apresentar defesa, por meio de defensor constituído ou dativo.

Foco deste trabalho, consideramos da maior relevância a criação do artigo 14-A do Código de Processo Penal, o qual deixa claro e expõe que agentes públicos vinculados ao artigo 144 da Constituição Federal têm o direito de serem citados na fase do inquérito policial toda vez que o objeto for a investigação de fatos relacionados ao uso da força letal praticados no exercício profissional, de forma consumada ou tentada, incluindo situações dispostas no artigo 23 do Decreto-Lei $n^{\circ} 2.848$, de 7 de setembro de 1940 (Código Penal).

O investigado poderá constituir defensor no prazo de até 48 horas a contar do recebimento da citação e, caso esse prazo tenha passado e o investigado não tenha um defensor, a autoridade responsável pela investigação deverá indicar um, defensor público ou dativo. Ressalte-se o parágrafo $6^{\circ}$ desse artigo 23 (BRASIL, 1940), segundo o qual essa norma deve também ser aplicada aos servidores militares vinculados às instituições dispostas no artigo 142 da Constituição Federal quando em missões para a garantia da lei e da ordem.

A amplitude dessa alteração promovida no art. 14-A do CPP é mencionada no caput como a circunstância para investigação de fatos relacionados ao uso de força letal, não somente se ocorrer homicídio, mas para todos os crimes em que seja necessário o uso de força letal, como tentativa de homicídio e lesões corporais. Como corolário, a garantia de citação do investigado a respeito da instauração do procedimento, conforme o parágrafo $1^{\circ}$ do art. 14-A do CPP, dispondo que após a citação haverá prazo de até 48 horas para a constituição de um advogado (HOFFMANN; COSTA; FONTES; SILVA, 2020).

Entendemos que essa inserção na lei de regência penal tenha vindo em prol da dignidade da pessoa humana, obrigando o Estado a garantir aos investigados ampla defesa e contraditório já na fase de investigação. $\mathrm{O}$ fez somente para os agentes aplicadores da lei, mas poderia, talvez devesse, ir além, ampliando essa garantia a todos os investigados, por isonomia.

Não vemos razão para um cidadão comum não ter o mesmo direito de ser citado, ou notificado como querem alguns autores, na fase pré-processual e com isso constituir defensor e produzir provas em seu favor. Como exemplo, citamos um cidadão que, em legítima defesa, mata um assaltante e poderia desde já ter conhecimento da investigação por meio da citação, ou notificação, e no inquérito policial 
contribuir com a investigação agregando provas (depoimentos testemunhais, câmeras de segurança etc.) para a opinio delicti do Delegado de Polícia.

Consideramos que em sede de inquérito policial, conforme Paula (2018, p. 195), devem vigorar os princípios do contraditório mitigado (contrariedade) e ampla defesa e, mais, em homenagem ao princípio do estado de inocência, a autoridade policial deve agir com ponderação e materializar o princípio da proporcionalidade. Afinal, nosso país é um Estado Democrático de Direito Humanitário e suas instituições devem atuar com isenção e impessoalidade, sendo transparentes e garantidoras dos direitos fundamentais.

\section{CONSIDERAÇÕES FINAIS}

Tradicionalmente, o inquérito policial é visto como procedimento administrativo com o objetivo de investigar fatos tipificados penalmente, de natureza inquisitória em que os imputados não gozam das prerrogativas do contraditório e da ampla defesa, além de não ser obrigatória a presença de um advogado.

Essa característica estaria justificada na interpretação feita do art. $5^{\circ}$, inciso $\mathrm{LV}$, da $\mathrm{CF} / 88$, pois o dispositivo menciona a garantia do contraditório e da ampla defesa aos litigantes e acusados em processos administrativos e judiciais, em cujo conceito não estaria incluído o inquérito policial, por ser considerado apenas um procedimento.

Entretanto, o presente trabalho buscou pincelar algumas das possíveis situações nas quais a ausência do contraditório e da ampla defesa em processos administrativos poderia causar prejuízos ao investigado, demonstrando assim a sua fundamental importância nas duas fases da persecução penal.

Um desses casos se revela nas provas irrepetíveis, em que não há possibilidade de uma segunda produção em fase judicial para que possam ser submetidas ao crivo do contraditório e da ampla defesa, como as perícias, ou ainda, em casos nos quais pode existir a necessidade de impetração de habeas corpus ou haveria interesse no requerimento de diligências pela parte investigada.

Além disso, outro ponto constante desse trabalho é a citação (ou notificação) do agente público em inquéritos e procedimentos extrajudiciais, a qual acarreta algumas peculiaridades a depender da pessoa citanda, além de ser etapa fundamental para que haja exercício das prerrogativas já mencionadas, relativas ao contraditório e à ampla defesa. A citação no processo civil é um ato de chamamento do réu, do executado ou interessado para que possa compor a relação processual, bem como para tomar ciência dos termos da demanda.

No âmbito administrativo, algumas vezes a nomenclatura encontrada é a citação, mesmo não se tratando de processo judicial com relação triangularizada, embora muitas vezes utilizem-se do termo notificação, como é o caso da Lei 9.784/99. Ocorrem diversas modalidades de citação de forma próxima ao que acontece nos processos judiciais, como: intimação por ciência no processo, intimação pessoal, intimação por carta com aviso de recebimento ou outro meio hábil a realizar a 
comunicação como telefone, meio eletrônico, existindo decisão que permite até mesmo a citação por edital.

No inquérito policial, utiliza-se o termo notificação, pois não se refere à hipótese que possui terceiro imparcial e como já mencionado, também não há obrigatoriedade na apresentação de defesa pelo investigado, em consequência, não é imperiosa a realização de sua citação ou notificação para tomar ciência dos termos dos atos constantes nos autos. Dessa forma, percebe-se a disparidade exposta ao se comparar o conteúdo de diversas leis relacionadas aos processos em âmbitos administrativos com a legislação do inquérito policial.

A divergência se dá em relação à exigência de notificação para ciência do acusado dos termos do processo, incluindo momento próprio para a defesa, a qual permite o exercício do contraditório e da ampla defesa, diferentemente do conteúdo da legislação referente ao inquérito policial, que não contém obrigatoriedade na realização de citação ou da apresentação de defesa, embora se trate de investigação que, ao final, pode levar a uma condenação criminal com a aplicação de penas que variam desde a multa até a privação da liberdade.

Na tentativa de diminuir esse prejuízo, surgiu o chamado Pacote Anticrime, traduzido pela Lei 13.964/2019, ocasionando alterações às leis penais e processuais penais, como a figura do juiz das garantias e, principalmente, a obrigatoriedade de citação do policial investigado em fatos provocados com o uso da força letal no exercício da profissão, o que, a nosso ver, corrobora a necessidade de observância dos princípios do contraditório e da ampla defesa em sede de inquérito policial.

\section{REFERENNCIAS}

AGRA, Walber de Moura. Curso de Direito Constitucional. 9. ed. Belo Horizonte: Fórum, 2018. 895

BOBBIO, Norberto. Teoria do Ordenamento Jurídico. 9. ed. Brasília: Editora Universidade de Brasília, 1995.

BRASIL, Controladoria-Geral da União (org.). Fases do Procedimento Disciplinar - Inquérito. Disponível em: https://corregedorias.gov.br/assuntos/perguntas-frequentes/ atividade-disciplinar-responsabilizacao/fases-do-procedimento-disciplinar-inquerito\#5. Acesso em: 02 out. 2020.

. Lei $\mathrm{n}^{\mathrm{o}} 13.245$, de 12 de janeiro de 2016. Altera o art. $7^{\circ}$ da Lei $\mathbf{n}^{\circ} 8.906$, de 4 de julho de 1994 (Estatuto da Ordem dos Advogados do Brasil). Disponível em <planalto.gov. br/ccivil_03/_Ato2015-2018/2016/Lei/L13245.htm> Acesso em 30/11/2020.

Superior Tribunal de Justiça (org.). Servidor alvo de processo administrativo disciplinar pode ser citado por edital. RMS 43.212/MT, Rel. Ministro Humberto Martins, Segunda Turma, julgado em 16/02/2016, DJe 24/02/2016. Disponível em: https:/ / www. conjur.com.br/2016-abr-27/servidor-alvo-processo-administrativo-citado-edital. Acesso em: 02 out. 2020. 
. Supremo Tribunal Federal (org.). Aplicação das Súmulas no STF. Súmula Vinculante $\mathrm{n}^{\mathrm{0}}$ 14. Disponível em: http://www.stf.jus.br/portal/jurisprudencia/menuSumario. asp?sumula=1230. Acesso em: 02 out. 2020. sília - DF. 1941.

. Código de Processo Penal. Decreto Lei n³.689, de 03 de outubro de 1941. BraCódigo Penal. Decreto Lei n².848, de 7 de dezembro de 1940. Brasília - DF. 1940.

.. Lei n ${ }^{0}$ 13.964, de 24 de dezembro de 2019. Institui o Código Civil. Diário Oficial da União; seção 1. Disponível em: <http:/ / www.planalto.gov.br/ccivil_03/_ato20192022/2019/lei/L13964.htm>. Acesso em: 06 mai. 2020.

.. Supremo Tribunal Federal. HC 82507, Órgão julgador: Primeira Turma, Relator(a): Min. SEPÚLVEDA PERTENCE, Julgamento: 10/12/2002, Publicação: 19/12/2002. Disponível em: https://jurisprudencia.stf.jus.br/pages/search?base=acordaos\&sinonimo=true\&plural=true\&page $=1 \&$ pageSize $=10 \&$ queryString $=82507 \&$ sort=_score \&sortBy $=$ desc.

.. Lei $n^{\circ}$ 13.105, de 16 de março de 2015. Código de Processo Civil. DAS NORMAS FUNDAMENTAIS E DA APLICAÇÃO DAS NORMAS PROCESSUAIS, Brasília, DF, 16 mar. 2015. Disponível em: http://www.planalto.gov.br/ccivil_03/_ato2015-2018/2015/ lei/113105.htm. Acesso em: 25 nov. 2021.

CAPEZ, Fernando. Curso de Processo Penal. 3. ed. São Paulo: Saraiva, 2005.

CAPEZ, Fernando. Curso de processo penal. 23. ed. São Paulo: Saraiva, 2016.

DIDIER JUNIOR, Fredie; ZANETTI JUNIOR., Hermes. Curso de Direito Processual Civil. 3 ed. Salvador: JusPODIUM, 2008, v.4.

DIDIER JÚNIOR, Fredie. Curso de direito processual civil - v. 1: introdução ao direito processual civil, parte geral e processo de conhecimento. 17. ed. Salvador: JusPODIVM, 2015.

DIDIER JÚNIOR, Fredie. Curso de direito processual civil: introdução ao direito processual civil, parte geral e processo de conhecimento. 19. ed. Salvador: Ed. Jus Podivm, 2017.

ESPÍNOLA FILHO, Eduardo. Código de Processo Penal Brasileiro Anotado. Rio de Janeiro: Ed. Rio, 1980.

FERNANDES, Antonio Scarance. Processo Penal Constitucional. 5.ed. São Paulo: RT, 2007.

FERNANDES, Antonio Scarance. Teoria geral do procedimento e o procedimento no processo penal. São Paulo: Revista dos Tribunais, 2005.

FOUCAULT, Michel. Vigiar e punir - História da violência nas prisões. Trad. Raquel Ramalhete. 12. ed. Petrópolis: Vozes, 1995

HOFFMANN, Henrique. COSTA, Adriano. FONTES, Eduardo. SILVA, Márcio Alberto Gomes. Defesa obrigatória e citação dos policiais no inquérito policial. 4 de agosto de 2020. Disponível em: <https://www.conjur.com.br/2020-ago-04/academia-policia-defesa-obrigatoria-citacao-policiais-inquerito-policial>. Acesso em: 25 de agosto de 2020. 
JUS BRASIL (ORG). Jurisprudência. Agravo Regimental no Agravo de instrumento. Disponível em: <https://stf.jusbrasil.com.br/jurisprudencia/2915585/agregno-agravo-de-instrumento-ai-agr-687893-pr>.

LIMA, Renato Brasileiro de. Manual de processo penal: volume único. 5. Ed. Salvador: JusPodivm, 2017.

LIMA, Renato Brasileiro. Manual de Processo Penal. Volume Único. $8^{\circ}$ ed. rev., amp. e atual. Salvador. Editora JusPodivm, 2020.

LOPES JUNIOR., Aury. Direito Processual Penal. 11 ed. São Paulo: Saraiva, 2014.

MARCÃO, Renato. Execução penal. São Paulo: Saraiva. 2012.

MENDES, André Pacheco Teixeira. Direito Penal Geral. FGV Direito Rio. Rio de Janeiro. 2015.

MIRABETE, Julio Fabrini. Processo Penal. 15. ed. São Paulo: Atlas, 2006.

MORAES, Alexandre de. Direito Constitucional. 3. ed. São Paulo: Atlas, 1998.

MORAES, Alexandre de. Direito constitucional. 33. ed. rev. e atual. até a EC no 95, de 15 de dezembro de 2016 - São Paulo: Atlas. 2017.

MOURA, Humberto Fernandes de. Princípios Constitucionais do Processo Penal Brasileiro. Brasília: Brasília Jurídica, 2006.

NUCCI, Guilherme de Souza. Pacote Ante Crime Comentado. Rio de Janeiro: Forense, 2020.

PACELLI, Eugênio. Curso de Processo Penal. 24. ed. São Paulo. Atlas. 2020.

PAULA, Fernando Shimidt de. Criptoindiciamento. São Bernardo do Campo. Universidade Metodista de São Paulo. 2018.

RANGEL, Paulo. Direito Processual Penal. 13. ed. Rio de Janeiro: Lúmen Júris, 2007.

RANGEL, Paulo. Direito Processual Penal. 27. ed. São Paulo: Atlas. 2019.

THEMUDO, Amanda Gabriela Gomes. LEI No 13.245/16: prerrogativas do advogado e a inquisitorialidade do inquérito policial. 2017. 87 f. TCC (Graduação) - Curso de Direito, Centro Universitário Antônio Eufrásio de Toledo de Presidente Prudente, Presidente Prudente, 2017. Disponível em: http://intertemas.toledoprudente.edu.br/index.php/Direito/article/view/6679. Acesso em: 21 ago. 2021.

THEODORO JÚNIOR, Humberto. Curso de Direito Processual Civil Volume1. $58^{\circ}$ Edição. Rio de Janeiro. Editora Forense, 2017.

TOURINHO FILHO, Fernando da Costa. Manual de Processo Penal. 9 ed. São Paulo: Saraiva, 2007. 